\title{
Student nurses, midwives and health visitors' attitudes, knowledge, and experience of complementary and alternative medicine in Hungary
}

\author{
Andrea Sárváry ${ }^{\mathrm{a}}$, Lívia Hajduné Demcsák ${ }^{\mathrm{b}}$, Sándorné Radób ${ }^{\mathrm{b}}$, Péter Takács ${ }^{\mathrm{c}}$, Attila \\ Sárváry ${ }^{b}$
}

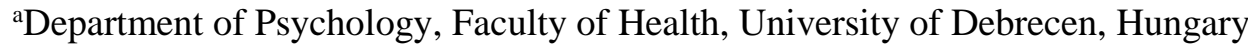
postal address: Faculty of Health, University of Debrecen, 4400 Nyíregyháza, Sóstói u. 2-4., Hungary

${ }^{b}$ Department of Nursing Science, Faculty of Health, University of Debrecen, Hungary

postal address: Faculty of Health, University of Debrecen, 4400 Nyíregyháza, Sóstói u. 2-4., Hungary

'Department of Health Informatics, Faculty of Health, University of Debrecen, Hungary

postal address: Faculty of Health, University of Debrecen, 4400 Nyíregyháza, Sóstói u. 2-4., Hungary

E-mail addresses: sarvary.andrea@foh.unideb.hu (A. Sárváry), hajdune.demcsak.livia@ foh.unideb.hu (L.H. Demcsák), rado.sandorne@ foh.unideb.hu (S. Radó), takacs.peter@ foh.unideb.hu (P. Takács), sarvary.attila@foh.unideb.hu (A. Sárváry)

\section{*Corresponding author:}

\section{Andrea Sárváry}

e-mail address: sarvary.andrea@foh.unideb.hu,

postal address: Faculty of Health, University of Debrecen, 4400 Nyíregyháza, Sóstói u. 2-4., Hungary phone number: +36 42 404411/147 


\begin{abstract}
Introduction: Complementary and alternative medicine (CAM) has become an important part of healthcare. This study aimed to compare three groups of health care students' attitudes towards, knowledge of, personal use of, and opinions about the integration of CAM into higher education and health care in Hungary. Comparisons were made between those participating and those who did not participate in a Complementary Medicine (CM) course as an optional course during student training.

Methods: A survey of the 314 full time students (nurses, midwives and health visitors) were asked to take part in an online survey using a self-complete questionnaire. Data were analyzed using descriptive statistics.

Results: Students' attitudes towards CAM were positive. The most commonly known alternative methods were massage, relaxation, acupuncture, herbal medicine and meditation. The most commonly personally used and perceived as being effective CAM modalities were herbal medicine, massage and relaxation. Most students believed that the integration of CAM into higher education and into health care is necessary. There were no differences in attitudes towards CAM between students who participated and those who did not participate in the CM course. Participants considered the course to be useful and reported higher knowledge about three CAM modalities and preferred formal education as information sources.

Conclusion: Health care students are open to learning CAM. Increasing the number of health care students in the CM courses would result in ensuring that future health care professionals obtain reliable knowledge about CAM practices which may in turn make their work more effective.
\end{abstract}

Key words: complementary and alternative medicine; attitude; knowledge; nursing, health visitor and midwifery students; Complementary Medicine course 


\section{Introduction}

The use of complementary and alternative medicine (CAM) for various health problems continues to increase worldwide [1-5]. Its popularity is similar or even higher among patients with chronic illnesses compared to the average population [1,6,7]. Since 2000s the number of evidence based CAM modalities has dramatically increased although evidence gaps still exist $[8,9]$. However, health care providers may not be aware of the evidence base and may be hard pressed to provide reliable advice to patients and inform them about the available therapeutic options and their use [10]. Moreover, the therapeutic approach of health professions, like nursing, midwifery and health visitors have been acknowledged as having a more holistic approach to care and welcomed more 'complementary' approaches to health $[11,12]$.

International research has investigated the knowledge about CAM and attitudes towards CAM among medical, pharmacy, nursing and midwifery students and different health professionals [10,12-19]. Most of the studies have shown positive attitudes towards CAM among health care students, but differences were found between genders, among years and specialties of the students [14-17]. Previous studies have also explored nurses' attitudes towards CAM, their knowledge about it and its professional use. Nurses' attitudes about CAM have been generally positive but their knowledge proved to be poor about the use of CAM modalities therefore they felt they could not give credible information and advice concerning CAM modalities [10,1821].

Since health care providers play an important role in the education of the patients, a high demand has emerged for educational institutions of health care workers to teach this discipline. The medical and health care educational organizations and institutions recognized the increasing demand of CAM and its integration into the curriculum. Different organizations developed recommendations and core curriculum for higher institutions in the USA. For example, the Society of Teachers of Family Medicine Group on Alternative Medicine developed a curriculum guideline [22] and the Education Working Group of the Consortium of Academic Health Centers for Integrative Medicine published a list of core competencies of integrative medicine for medical universities developed by 23 academic health centers [23]. The American Association Colleges of Nursing in the core curriculum outlined in 1998 also included the main elements of CAM desired to integrate it to the curriculum. [24]. As early as 1999, the support the integration of CAM into the education the National Institute of Health and the National Center for Complementary and Alternative Medicine (now National Center for Complementary and Integrative Medicine - NCCIM) funded 14 higher institutions to perform such programs [25]. It is important to note that since 2015 the NCCIM has been using the term Complementary Health Approach instead of Complementary and Alternative Medicine.

Previous studies revealed that there was no difference concerning the need for the integration of CAM into the curriculum among students $[15,16]$. In a study from Turkey comparing nursing and medical students' knowledge and attitude towards CAM showed significant difference between the two groups both in integration of CAM into clinical practice (57.8\% vs. $32.6 \%$ ) and into curriculum $(61.3 \%$ vs. $37.9 \%)$ with the higher rate of nurses [13]. However, these results were not strengthened by another study carried out at seven faculties of medicine covered all region of Turkey [14]. According to the results of this study, medical students with high rate believed that CAM should be included in the curriculum, knowledge of CAM would be useful in their professions, and doctors should be familiar with CAM methods [14]. These results were also supported by a study from Kuwait [15]. 
During the era of socialism in Hungary only some types of CAM were tolerated (e.g. herbal medicine). Different types of CAM appeared at the end of the 1980s and since the change of the regime a rapid increase has occurred in this field. The market relating to CAM was uncontrolled for a long time and the regulation of CAM entered into force only in 1997 [26]. The decree (11/1997 (V. 28) NM rend.) lists the types of non-conventional therapies and determines which ones can be performed by medical doctor only (e.g. manual therapies, Traditional Chinese Medicine, neural therapies) or by other graduations (e.g. acupressure, reflexology). Although the education of the Traditional Chinese Medicine started in 1987 at a medical university, the introduction of optional courses of some types of CAM did not begin until the end of the 1990s in other medical universities [26]. In Hungary, the education of health visitors (started in 1975) and midwives (started in 2004) is at BSc level in higher education. Nursing students' education is at three different levels: at vocational school, in higher education at BSc (started in 1989) and at MSc level (started in 2010). Health visitors are preventive professionals, who care for children until 18 years. They work in districts with close connections with pediatric family doctors/general practitioners or in schools. Using CAM therapies health care providers have a good opportunity to press patients to take part in their care and healing process actively [10,12]. Thus the knowledge of CAM has become very important to nursing practice [12] and to the practice of other health professions. At the University of Debrecen, Faculty of Health the education of CAM for nurses and health visitors and later on for midwives also started in 1995 titled Complementary Medicine course.

There is only limited data concerning the use of CAM in Hungary. Two national representative surveys showed a significant increase in visiting CAM practitioners from $6.6 \%$ to $23.9 \%$ from 1991 to 1999 [27,28]. However, based on the data from the national representative health surveys in 2000, only a small number of the Hungarian population consulted CAM practitioners in the previous 12 months (males: 3\%, females: 4\%) and this slightly increased to 2003 (males: $3.6 \%$, females: 6.1\%) [29,30]. It is important to note that these rates did not include those CAM therapies, which were used as home remedies or self-treatment. There was also no distinction between those visiting physicians who were also CAM therapists and those visiting only CAM practitioners. Therefore, these rates may underestimate the real use of CAM and are not comparable with the aforementioned national data or with the international data.

In the literature there have been only a few studies comparing attitudes towards CAM and its knowledge in different groups of health care students [13,16,31], and no surveys were found from Hungary. Nurses, midwives and health visitors spend the most time with patients during their health care. Therefore the primary aim of the research was to investigate and compare nursing, health visitor and midwifery students' attitudes and knowledge towards CAM, its personal use and its perceived effectiveness. In addition, the study aimed to reveal the information sources used by these students and their opinions about the integration of CAM into high education as well as health care system in Hungary. As the third aim of the study comparisons were made between students who participated and those who did not participate in the Complementary Medicine course.

\section{Methods}

\subsection{Study Questionnaire}

A cross-sectional survey was designed using a self-administered questionnaire. The eighteen CAM therapies included were: Traditional Chinese Medicine, acupuncture, homeopathy, meditation, relaxation techniques, hypnotherapy, Mind Control (relaxation technique), 
magnets, Prananadi ${ }^{1}$, Reiki ${ }^{2}$, therapeutic touch, kinesiology, massage, acupressure, chiropractic, reflexology, herbal medicine and non-herbal supplements [20]. Some of these therapies were selected due to their popularity in Hungary.

The term alternative medicine was defined in the questionnaire as follows: 'a group of diverse medical and health care systems, practices, and products that are not generally considered part of conventional medicine, and are not taught in medical universities, and are not used in hospitals and are not integrated into the dominant health care system and most of them can be practiced without having M.D. (medical doctor) degrees' [32,33].

The questionnaire was pre-tested among 8 students for content, language clarity, easy for use, and time required to fill out the questionnaire. Modifications were made as necessary in order that the questionnaire could be simple to answer.

\subsubsection{General attitudes towards CAM}

The students' general attitudes towards CAM were measured by an item list. After selecting statements based on other questionnaires [34,35], eight experts (six women and two men) classified them as follows: items accepted by people characterized with a positive and accepting attitude toward CAM (Group A); those with negative (rejecting) attitude (Group B); and those that are neutral (neither accepting nor rejecting) (Group C). Those items were selected in the final list, which had been considered to characterize negative or positive attitude toward CAM by all experts. The final version consisted of 7 positive (see table $2: 1-7$ statements) and 5 negative statements (see table 2: 8-12 statements). Responses were given on a 7 point Likerttype scales, ranging from 1 (strongly disagree) to 7 (strongly agree).

\subsubsection{Knowledge of CAM}

Students were asked to indicate their knowledge about each CAM modality using a 4-point scale (none, very little, some, a lot).

\subsubsection{Information sources}

Students were asked to indicate sources where their knowledge about CAM comes from by responding 'yes' or 'no'. The following knowledge source categories were given: 'scientific journals or books'; 'TV or radio'; 'the Internet'; ' other people (family members, relatives, friends)'; 'newspapers or magazines'; 'formal education', 'special courses' and 'health care related professions'.

\subsubsection{Personal use and perceived effectiveness of CAM}

Students were asked to respond using 'yes' or 'no' with reference to 18 CAM practices and if used to assess their effectiveness on a 7-point Likert-type scale ranging from 1 (it was completely ineffective) to 7 (it was completely effective).

\subsubsection{Integration of CAM into higher education and health care system}

Students were asked to indicate how much they agree with four items concerning integration of CAM modalities into undergraduate curriculum and health care system on a 7-point Likert-type scale ranging from 1 (strongly disagree) to 7 (strongly agree).

\subsubsection{Evaluation of Complementary Medicine course}

Complementary Medicine course is a two semester optional course, which can be chosen by 2nd, 3rd and 4th years health care students. The course contains theory (14 hours) and practice ( 28 hours) in both semesters. Lectures cover the most popular and the most widely used CAM and other treatment methods in Hungary (e.g.: basic of Traditional Chinese Medicine, herbal medicine, acupuncture, massage, chiropractic, balneotherapy). During this two semester course 
students obtain knowledge about indications and contraindications of CAM therapies, about their efficiency and about their side effects. On the practice the teacher presents the most frequently used CAM techniques, e.g. preparing methods and indications of herb teas, compress and balneotherapy, moxa treatment, manual therapy, acupuncture and chiropractic. The course is taught by a physician, acupuncture practitioner, who is responsible for the content of the program. Students were asked to indicate ('yes' or 'no') whether they had participated in the Complementary Medicine course and how much of it was useful on a 7-point Likert-type scale ranging from 1 (it was completely useless) to 7 (it was completely useful). Further, they were asked to indicate the appropriate form of education of this subject: optional, elective or compulsory course. (Optional course: during their studies students can freely choose courses from a given list of courses that are not absolutely related to their specialty. Elective course: during their studies students have to select courses from a given list of courses that are connected to their specialty.)

\subsection{Study sample}

The study sample consisted of students in Faculty of Health at the University of Debrecen from $1 \mathrm{st}, 2 \mathrm{nd}, 3 \mathrm{rd}$ and 4 th years. The sample was composed of the all full time nursing (124), midwifery (204) and health visitor (196) students (524, females: 506, males: 18).

As the study aimed to make comparisons between students who participated (131) and those who did not participate (63) in Complementary Medicine course 2nd, 3rd and 4th year students consisted a subsample (194). First year students were excluded from the subsample, because they had no possibility to take part in this course.

\subsection{Data collection}

The study was conducted at the University of Debrecen, Faculty of Health in Nyíregyháza between April and June 2013. The Eva-sys online version of the questionnaire was used in order to increase the efficiency of data collection. Data collection took place during seminars when computers were available for students. Students had one occasion to complete the questionnaire. Before filling in the questionnaire the students were given a brief description of what the study entailed. The participation in the study was voluntary. Written permission to proceed the research was obtained from the University of Debrecen Faculty of Health.

\subsection{Statistical analysis}

Data were evaluated with the help of Statistical Package for Social Sciences (SPSS) software program (Version 22.0).

Similarly to other studies [36,37], all Likert-scale responses with any degree of agreement were grouped together as positive responses, and all responses with any degree of disagreement were grouped together as negative responses. For instance, 'agreed a little' and 'agreed moderately' and 'agreed strongly' (indicating 5 or 6 or 7 on the Likert scale) were considered and grouped together as positive response.

To evaluate respondents' attitudes, a scale was developed from the 12 statements. Since, the internal consistency of this measure was found high (Cronbach's coefficient alpha $=0.851$, Guttman $\lambda_{2}=0.858$ ), this measure was found reliable. To summarize the data, descriptive statistics were used. ANOVA was used to reveal whether the difference of Likert scale averages is significant among nursing, health visitor and midwifery students. An independent sample Ttest was used to reveal whether the difference of Likert scale averages is significant between students who participated and those who did not participate in the Complementary Medicine course. Simple cross-tabulations, Chi-square tests (Pearson) and Fisher exact test were used toanalyze differences in agreeing with statements, knowledge, personal use, perceived effectiveness of CAM, information sources, and opinion about the integration of CAM among 
the three groups of health care students, and between students who participated and those who did not participate in the Complementary Medicine course. Results were considered to be significant when the $\mathrm{p}$ value was less than 0.05 .

\section{Results}

Three hundred and fourteen students (females: 299, males: 15) completed the questionnaire from 1st, 2nd, 3rd and 4th years, giving a response rate of 59.9\% (314/524). Our study sample was representative with the respect to proportions of gender and specialties of students.

Respondents consisted of three groups: 83 (26.4\%) nurses, $126(40.1 \%)$ midwives and 105 (33.4\%) health visitors. Data were collected from 1st (120, 38.2\%), 2nd (74, 23.6\%), 3rd (79, $25.2 \%)$ and 4 th $(41,13.1 \%)$ year students (Table 1$)$. The mean age was 21.6 years (range 18$31)$.

Table 1 Year and specialty characteristics of the study sample

\begin{tabular}{|l|c|c|c|c|c|}
\hline \multirow{2}{*}{$\begin{array}{c}\text { Specialty of } \\
\text { students }\end{array}$} & \multicolumn{4}{|c|}{ Year No (\%) } & $\begin{array}{c}\text { Total } \\
\text { No (\%) }\end{array}$ \\
\cline { 2 - 6 } & $28(33.7)$ & $30(36.1)$ & $23(27.7)$ & $2(2.4)$ & $\begin{array}{c}83 \\
(26.4)\end{array}$ \\
\hline nursing & $48(38.1)$ & $23(18.3)$ & $35(27.8)$ & $20(15.9)$ & $\begin{array}{c}126 \\
(40.1)\end{array}$ \\
\hline midwifery & & & & & $\begin{array}{c}105 \\
(33.4)\end{array}$ \\
\hline health visitor & $44(41.9)$ & $23(21.9)$ & $19(18.1)$ & $19(18.1)$ & 314 \\
& & & & & 41 \\
\hline Total No (\%) & 120 & 76 & 77 & $(13.1)$ & $(100)$ \\
\hline
\end{tabular}

As for the subsample, one hundred and thirty one students participated in the Complementary Medicine course from 2nd, 3rd and 4th year (131/194, 67.5\%): 33 (33/57, 57.9\%) nurses, 48 $(48 / 78,61.5 \%)$ midwives and $50(50 / 59,84.7 \%)$ health visitors. This optional course was the most popular among health visitor students (Table 2).

Table 2 Nursing, Midwifery and Health Visitor Students participating in the Complementary Medicine course

\begin{tabular}{|l|c|c|c|c|c|c|c|c|c|}
\hline \multirow{2}{*}{ Year } & \multicolumn{8}{|c|}{ Participating in the Complementary Medicine course No. } \\
\cline { 2 - 11 } & \multicolumn{3}{|c|}{ Nursing students } & \multicolumn{3}{c|}{ Midwifery students } & \multicolumn{3}{c|}{ Health visitor students } \\
\cline { 2 - 10 } & total & yes & no & total & yes & no & total & yes & no \\
\hline 2nd (n=74) & 30 & 14 & 16 & 23 & 6 & 17 & 21 & 14 & 7 \\
\hline 3rd (n=79) & 25 & 17 & 8 & 35 & 24 & 11 & 19 & 19 & 0 \\
\hline 4th (n=41) & 2 & 2 & 0 & 20 & 18 & 2 & 19 & 17 & 2 \\
\hline $\begin{array}{l}\text { total } \\
\text { (n=194) }\end{array}$ & 57 & 33 & 24 & 78 & 48 & 30 & 59 & 50 & 9 \\
\hline
\end{tabular}

\subsection{General attitudes towards CAM}


In general, all three groups of students' attitudes were found to be positive according to the Likert scale averages: midwives' attitudes were the most positive (Mean $(\mathrm{M})=5.08$, standard deviation $(\mathrm{std})=0.96)$, followed by health visitors $(M=5.02$, std $=0.92)$ and nurses $(M=4.93$, std $=0.77)$. There were no significant differences in nursing, health visitor and midwifery students' attitudes $(\mathrm{p}=0.511)$. There were no significant differences $(\mathrm{p}=0.322)$ in attitudes between the groups who participated in the Complementary Medicine course $(M=5.3$, std= $0.9)$ and those who did not $(\mathrm{M}=5.1, \mathrm{std}=0.8)$.

Over $70 \%$ of the students agreed (Table 3 ) that CAM brings about an improvement in patients' well-being $(232,74.4 \%)$, and considered it to be a useful supplement to regular medicine (227, $72.3 \%)$. Most students also believed that CAM does have important results $(225,71.9 \%)$ and it can provide an answer in cases where conventional medicine has no solution $(223,71.7 \%)$. Over one-third of students believed that the results of CAM are in most cases due to a 'placeboeffect' $(118,37.7 \%)$. Furthermore, approximately one-quarter of students believed that CAM was dangerous because it raised unfounded hopes and may lead to disappointment later (87, $27.7 \%$ ) and that patients almost never get better using only CAM $(69,22.0 \%)$. Less than $20 \%$ of students considered CAM to be dangerous because it increases the possibility of negative side effects $(52,16.9 \%)$ and a minority of students agreed that treatment with CAM modalities should be forbidden by law $(31,9.9 \%)$. There was a significant difference between nursing $(51$, $61.4 \%)$, health visitor $(75,73.5 \%)$ and midwifery students' $(97,77.0 \%)$ opinions regarding whether CAM treatments can provide an answer in cases where conventional medicine has no solution $(\mathrm{p}=0.045)$. There were no significant differences in the attitude statements between students who participated and those who did not participate in the Complementary Medicine course.

Table 3 Nursing, Health Visitor and Midwifery Students' General Attitudes towards Complementary and Alternative Medicine (CAM)

\begin{tabular}{|c|c|c|c|c|c|}
\hline \multirow[b]{2}{*}{ Statements } & \multicolumn{5}{|c|}{$\begin{array}{l}\text { Agreed* } \\
\text { No. }(\%)\end{array}$} \\
\hline & $\begin{array}{l}\text { total } \\
\text { No. }(\%) \\
\mathrm{N}=314\end{array}$ & $\begin{array}{l}\text { nurses } \\
\text { No. }(\%) \\
\mathrm{N}=83\end{array}$ & $\begin{array}{l}\text { health } \\
\text { visitors } \\
\text { No. }(\%) \\
\mathrm{N}=105\end{array}$ & $\begin{array}{l}\text { midwive } \\
\text { s } \\
\text { No. }(\%) \\
\mathrm{N}=126\end{array}$ & $\mathrm{p}$ \\
\hline $\begin{array}{l}\text { 1. CAM brings about an improvement } \\
\text { in patients' well-being. }\end{array}$ & $232(74.4)$ & $56(68.3)$ & $78(75.0)$ & $98(77.8)$ & 0.305 \\
\hline $\begin{array}{l}\text { 2. CAM is useful supplement to } \\
\text { regular medicine. }\end{array}$ & $227(72.3)$ & $57(68.7)$ & $81(77.1)$ & $89(70.6)$ & 0.377 \\
\hline 3. CAM does have important results. & $225(71.9)$ & $57(68.7)$ & $75(71.4)$ & $93(74.4)$ & 0.662 \\
\hline $\begin{array}{l}\text { 4. CAM treatments can provide an } \\
\text { answer in cases where conventional } \\
\text { medicine has no solution. }\end{array}$ & $223(71.7)$ & $51(61.4)$ & $75(73.5)$ & $97(77.0)$ & 0.045 \\
\hline $\begin{array}{l}\text { 5. I believe that CAM may have } \\
\text { positive effect on general health } \\
\text { outcomes. }\end{array}$ & $209(67.0)$ & $53(64.6)$ & $70(67.3)$ & $86(68.3)$ & 0.860 \\
\hline $\begin{array}{l}\text { 6. I believe in alternative approaches } \\
\text { in health area. }\end{array}$ & $196(63.0)$ & $50(61.0)$ & $66(63.5)$ & $80(64.0)$ & 0.902 \\
\hline
\end{tabular}




\begin{tabular}{|l|c|c|c|c|c|}
\hline $\begin{array}{l}\text { 7. CAM has advanced considerably in } \\
\text { recent years in understanding of } \\
\text { illness and diseases. }\end{array}$ & $168(53.5)$ & $45(54.2)$ & $59(56.2)$ & $64(50.8)$ & 0.707 \\
\hline $\begin{array}{l}\text { 8. The results of CAM are in most } \\
\text { cases due to a 'placebo-effect'. }\end{array}$ & $118(37.8)$ & $31(37.8)$ & $46(43.8)$ & $41(32.8)$ & 0.230 \\
\hline $\begin{array}{l}\text { 9. The increase in CAM use is } \\
\text { dangerous because it raises } \\
\text { unfounded hopes and leads to } \\
\text { disappointment later. }\end{array}$ & $87(27.7)$ & $22(26.5)$ & $27(25.7)$ & $38(30.2)$ & 0.724 \\
\hline $\begin{array}{l}\text { 10. Patients almost never get better using } \\
\text { only CAM. }\end{array}$ & $69(22.0)$ & $15(18.1)$ & $24(22.9)$ & $30(23.8)$ & 0.597 \\
\hline $\begin{array}{l}\text { 11. The increase in CAM use is } \\
\text { dangerous because it increases the } \\
\text { possibility of negative side effects. }\end{array}$ & $52(16.9)$ & $9(11.1)$ & $22(21.6)$ & $21(16.8)$ & 0.172 \\
\hline $\begin{array}{l}\text { 12. Treatment with CAM modalities } \\
\text { should be forbidden by law. }\end{array}$ & 31 (9.9) & $4(4.8)$ & $13(12.4)$ & $14(11.1)$ & 0.188 \\
\hline
\end{tabular}

\subsection{Knowledge of CAM}

More than $80 \%$ of the study participants reported (Table 4) that they knew something or a lot about massage $(269,86.5 \%)$. The knowledge about the other modalities (over $60 \%$ ) was as follows: relaxation $(242,77.3 \%)$, acupuncture $(211,67.8 \%)$, herbal medicine $(207,66.6 \%)$, meditation $(206,66.5 \%)$ and homeopathy $(204,66.0 \%)$. Among the least known types of CAM were kinesiology $(36,11.6 \%)$, Reiki $(34,10.9 \%)$ and Prananadi $(22,7.1 \%)$. There was no significant difference between the three groups' knowledge about CAM modalities. However, significant differences were found between students who participated and those who did not participate in the Complementary Medicine course in the knowledge about Traditional Chinese Medicine $(58,45.0 \%$, vs. $18,29.0 \%, \mathrm{p}=0.027)$, acupuncture $(99,76.2 \%$, vs. $37,59.7 \%, \mathrm{p}=$ $0.011)$ and chiropractic $(80,61.1 \%$, vs. $29,46.0 \%, \mathrm{p}=0.032)$.

Table 4 Nursing, Health Visitor and Midwifery Students' Knowledge of CAM modalities

\begin{tabular}{|l|c|c|c|c|c|}
\hline \multirow{2}{*}{ CAM modalities } & \multicolumn{5}{|c|}{$\begin{array}{c}\text { Knowledge* } \\
\text { No. }(\%)\end{array}$} \\
\cline { 2 - 6 } & $\begin{array}{c}\text { Total } \\
\mathrm{N}=314\end{array}$ & $\begin{array}{c}\text { Nurses } \\
\mathrm{N}=83\end{array}$ & $\begin{array}{c}\text { Health visitors } \\
\mathrm{N}=105\end{array}$ & $\begin{array}{c}\text { Midwives } \\
\mathrm{N}=126\end{array}$ & $\mathrm{p}$ \\
\hline massage & $269(86.5)$ & $73(88.0)$ & $87(84.5)$ & $109(87.2)$ & 0.753 \\
\hline relaxation & $242(77.3)$ & $57(69.5)$ & $86(81.9)$ & $99(78.6)$ & 0.121 \\
\hline acupuncture & $211(67.8)$ & $59(71.1)$ & $77(74.0)$ & $75(60.5)$ & 0.070 \\
\hline herbal medicine & $207(66.6)$ & $55(66.3)$ & $69(67.0)$ & $83(66.4)$ & 0.993 \\
\hline meditation & $206(66.5)$ & $56(68.3)$ & $75(72.1)$ & $75(60.5)$ & 0.165 \\
\hline homeopathy & $204(66.0)$ & $53(64.6)$ & $75(71.4)$ & $76(62.3)$ & 0.334 \\
\hline chiropractic & $181(58.4)$ & $45(54.2)$ & $65(64.4)$ & $71(56.3)$ & 0.318 \\
\hline Traditional Chinese & $126(40.5)$ & $33(40.2)$ & $39(37.1)$ & $54(43.5)$ & 0.615 \\
Medicine & & & & & \\
\hline non-herbal supplements & $124(40.3)$ & $34(42.0)$ & $42(40.4)$ & $48(39.0)$ & 0.915 \\
\hline Mind Control & $124(40.0)$ & $37(45.1)$ & $43(41.3)$ & $44(35.5)$ & 0.363 \\
\hline acupressure & $113(36.6)$ & $31(38.3)$ & $39(38.2)$ & $43(34.1)$ & 0.761 \\
\hline hypnotherapy & $108(35.0)$ & $24(30.0)$ & $39(37.5)$ & $45(36.0)$ & 0.543 \\
\hline
\end{tabular}




\begin{tabular}{|l|c|c|c|c|c|}
\hline reflexology & $85(27.5)$ & $29(35.8)$ & $27(26.5)$ & $29(23.0)$ & 0.127 \\
\hline magnets & $76(24.5)$ & $24(29.6)$ & $24(23.1)$ & $28(22.4)$ & 0.458 \\
\hline therapeutic touch & $53(17.2)$ & $17(20.7)$ & $15(14.6)$ & $21(16.9)$ & 0.541 \\
\hline kinesiology & $36(11.6)$ & $15(18.3)$ & $7(6.8)$ & $14(11.2)$ & 0.052 \\
\hline Reiki & $34(10.9)$ & $11(13.4)$ & $8(7.7)$ & $15(12.0)$ & 0.409 \\
\hline Prananadi & $22(7.1)$ & $9(10.8)$ & $5(4.9)$ & $8(6.4)$ & 0.265 \\
\hline
\end{tabular}

*Percentages of 'knowing some' and 'knowing a lot' responses were combined

\subsection{Personal use and perceived effectiveness of CAM}

The most commonly used (over 50\%) CAM practices among students were (Table 5) herbal medicine $(186,59.2 \%)$ followed by massage therapy $(180,57.3 \%)$ and relaxation $(166,52.9 \%)$. Among the least used types of CAM were kinesiology $(41,13.1 \%)$ and Prananadi $(40,12.7 \%)$. There were significant differences in personal using between nursing, health visitor and midwifery students with the following five CAM modalities: herbal medicine $(55,66.3 \%$ vs. $50,47.6 \%$ vs. $81,64.3 \%$, respectively), massage (58, $69.9 \%$ vs. $46,43.8 \%$ vs. $76,60.3 \%$, respectively), chiropractic $(29,34.9 \%$ vs. $21,20.0 \%$ vs. $45,35.7 \%$, respectively), acupressure $(26,31.3 \%$ vs. $14,13.3 \%$ vs. $28,22.2 \%$, respectively) and reflexology $(26,31.3 \%$ vs. $13,12.4 \%$ vs. $27,21.4 \%$, respectively). Significant differences were found between students who participated and those who did not participate in the Complementary Medicine course in using Traditional Chinese Medicine (30, $22.9 \%$ vs. $6,9.5 \%, \mathrm{p}=0.048)$, acupressure $(24,18.3 \%$ vs. $4,6.5 \%, \mathrm{p}=0.027)$ and reflexology $(24,18.3 \%$ vs. $4,6.3 \%, \mathrm{p}=0.027)$. The highest effectiveness was experienced in massage $(170,54.1 \%)$, herbal medicine $(144,45.9 \%)$ and relaxation $(126,40.1 \%)$ while the lowest effectiveness was found in hypnotherapy $(13,4,1 \%)$, kinesiology $(12,3.8 \%)$ and Prananadi $(8,2.5 \%)$.

Table 5 Nursing, Health Visitor and Midwifery Students' Personal Use and Perceptions about Effectiveness of CAM modalities

\begin{tabular}{|c|c|c|c|c|c|c|}
\hline \multirow[b]{2}{*}{ CAM modalities } & \multicolumn{5}{|c|}{$\begin{array}{l}\text { Personal use } \\
\text { No }(\%)\end{array}$} & \multirow{2}{*}{$\begin{array}{c}\text { Perceived } \\
\text { Effectiveness } * \\
\text { Total } \\
\text { No }(\%) \\
\mathrm{N}=314\end{array}$} \\
\hline & $\begin{array}{c}\text { Total } \\
\mathrm{N}=314\end{array}$ & $\begin{array}{l}\text { Nurses } \\
\mathrm{N}=83\end{array}$ & $\begin{array}{c}\text { Health } \\
\text { visitors } \\
\mathrm{N}=105\end{array}$ & $\begin{array}{l}\text { Midwives } \\
\mathrm{N}=126\end{array}$ & $\mathrm{p}$ & \\
\hline herbal medicine & $186(59.2)$ & $55(66.3)$ & $50(47.6)$ & $81(64.3)$ & 0.012 & $144(45.9)$ \\
\hline massage & $180(57.3)$ & $58(69.9)$ & $46(43.8)$ & $76(60.3)$ & 0.001 & $170(54.1)$ \\
\hline relaxation & $166(52.9)$ & $41(49.4)$ & $52(49.5)$ & $73(57.9)$ & 0.338 & $126(40.1)$ \\
\hline homeopathy & $146(46.5)$ & $40(48.2)$ & $47(44.8)$ & $59(46.8)$ & 0.892 & $90(28.7)$ \\
\hline meditation & $125(39.8)$ & $34(41.0)$ & $37(35.2)$ & $54(42.9)$ & 0.484 & $73(23.2)$ \\
\hline non-herbal supplements & $118(37.6)$ & $35(42.2)$ & $34(32.4)$ & $49(38.9)$ & 0.359 & $54(17.2)$ \\
\hline $\begin{array}{l}\text { Traditional Chinese } \\
\text { Medicine }\end{array}$ & $114(36.3)$ & $35(42.2)$ & $37(35.2)$ & $42(33.3)$ & 0.413 & $42(13.4)$ \\
\hline acupuncture & $109(34.7)$ & $31(37.3)$ & $35(33.3)$ & $43(34.1)$ & 0.835 & $49(15.6)$ \\
\hline Mind Control & $99(31.5)$ & $27(32.5)$ & $30(28.6)$ & $42(33.3)$ & 0.721 & $40(12.7)$ \\
\hline chiropractic & $95(30.3)$ & $29(34.9)$ & $21(20.0)$ & $45(35.7)$ & 0.019 & $69(21.9)$ \\
\hline hypnotherapy & $81(25.8)$ & $25(30.1)$ & $21(20.0)$ & $35(27.8)$ & 0.233 & $13(4.1)$ \\
\hline acupressure & $68(21.7)$ & $26(31.3)$ & $14(13.3)$ & $28(22.2)$ & 0.012 & $26(8.3)$ \\
\hline reflexology & $66(21.0)$ & $26(31.3)$ & $13(12.4)$ & $27(21.4)$ & 0.007 & $23(7.3)$ \\
\hline
\end{tabular}




\begin{tabular}{|l|c|c|c|c|c|c|}
\hline magnets & $57(18.2)$ & $18(21.7)$ & $12(11.4)$ & $27(21.4)$ & 0.091 & $22(7.0)$ \\
\hline Reiki & $52(16.6)$ & $18(21.7)$ & $10(9.5)$ & $24(19.0)$ & 0.052 & $20(6.4)$ \\
\hline therapeutic touch & $48(15.3)$ & $15(18.1)$ & $9(8.6)$ & $24(19.0)$ & 0.063 & $19(6.1)$ \\
\hline kinesiology & $41(13.1)$ & $15(18.1)$ & $9(8.6)$ & $17(13.5)$ & 0.156 & $12(3.8)$ \\
\hline Prananadi & $40(12.7)$ & $15(18.1)$ & $8(7.6)$ & $17(13.5)$ & 0.097 & $8(2.5)$ \\
\hline
\end{tabular}

* Percentages of 'effective a little' and 'moderately effective' and 'completely effective' responses were combined

\subsection{Information sources}

Over $80 \%$ of respondents (Table 6) obtained information on CAM through the Internet (260, $82.8 \%)$ and over $50 \%$ of them got their knowledge from TV or radio $(180,57.3 \%)$ and other people $(177,56.4 \%)$. The other information sources were as follows: formal education (152, $48.4 \%)$, scientific journals or books $(145,46.2 \%)$, newspapers or magazines $(70,22.3 \%)$. Only a fraction of them used special courses $(21,6.7 \%)$ or health care related professions $(9,2.9 \%)$ as information sources. The only significant difference in getting information on CAM between nursing, health visitor and midwifery students was in using TV or radio (40, 48.2\% vs. 70 , $66.7 \%$ vs. $70,55.6 \%$, respectively) as information source. Significant differences were observed between students who participated and those who did not participate in the Complementary Medicine course in using scientific journals or books (58, 44.3\%, vs. 40, $63.5 \%, \mathrm{p}=0.025)$ and formal education $(88,67.2 \%$ vs. $29,46.0 \%, \mathrm{p}=0.001)$.

Table 6 Sources of Information for Complementary and Alternative Medicine Used by Nursing, Health Visitor and Midwifery Students

\begin{tabular}{|l|c|c|c|c|c|}
\hline \multicolumn{1}{|c|}{ Sources } & total & nurses & $\begin{array}{c}\text { health } \\
\text { visitors } \\
\text { No. }(\%) \\
\mathrm{N}=105\end{array}$ & $\begin{array}{c}\text { midwives } \\
\mathrm{N}=1 \%)\end{array}$ & $\mathrm{p}$ \\
\hline the Internet & $260(82.8)$ & $69(83.1)$ & $91(86.7)$ & $100(79.4)$ & 0.341 \\
\hline TV or radio & $180(57.3)$ & $40(48.2)$ & $70(66.7)$ & $70(55.6)$ & 0.034 \\
\hline $\begin{array}{l}\text { other people ( family members, } \\
\text { relatives and friends) }\end{array}$ & $177(56.4)$ & $46(55.4)$ & $67(63.8)$ & $64(50.8)$ & 0.136 \\
\hline formal education & $152(48.4)$ & $43(51.8)$ & $50(47.6)$ & $59(46.8)$ & 0.765 \\
\hline scientific journals or books & $145(46.2)$ & $43(51.8)$ & $52(49.5)$ & $50(39.7)$ & 0.160 \\
\hline newspapers or magazines & $70(22.3)$ & $15(18.1)$ & $29(27.6)$ & $26(20.6)$ & 0.250 \\
\hline special courses & $21(6.7)$ & $8(9.6)$ & $3(2.9)$ & $10(7.9)$ & 0.139 \\
\hline health care related professions $*$ & $9(2.9)$ & $3(3.6)$ & $4(3.8)$ & $2(1.6)$ & 0.537 \\
\hline
\end{tabular}

*Fisher's exact test (cell sizes $<5$ )

\subsection{Integration of CAM into higher education and health care system}

About $60 \%$ of respondents (Table 7) indicated that CAM should be researched $(192,61.7 \%$ ) and that integration of CAM methods into health care would be effective $(183,58.7 \%)$ and only evidence based CAM methods should be taught $(182,58.5 \%)$, and CAM should be taught in higher education in the field of medical and health sciences (179, 57.2\%). Significant differences were observed between nursing, health visitor and midwifery students' opinions regarding whether CAM should be further researched (44, 54.3\% vs. $74,71.2 \%$ vs. $74,58.7 \%$, 
respectively), and whether integration of CAM methods into health care would be effective (44, $53.7 \%$ vs. $73,69.5 \%$ vs. $66,52.8 \%$, respectively), and whether only evidence based CAM methods should be taught $(49,59.8 \%$ vs. $71,68.3 \%$ vs. $62,49.6 \%$, respectively). There were significant differences between students who participated and those who did not participate in the Complementary Medicine course whether integration of CAM methods into health care would be effective $(96,73.3 \%$ vs. $34,54.0 \%, p=0.038)$ and whether only evidence based CAM methods should be taught $(93,71.5 \%$ vs. $33,52.4 \%, \mathrm{p}=0.040)$.

Table 7 Nursing, Health Visitor and Midwifery Students' Opinion about Integration of CAM into Higher Education and Health Care

\begin{tabular}{|l|c|c|c|c|c|}
\hline \multicolumn{1}{|c|}{ Statements } & \multicolumn{5}{c|}{$\begin{array}{c}\text { Agreed* } \\
\text { No. (\%) }\end{array}$} \\
\cline { 2 - 6 } & $\begin{array}{c}\text { Total } \\
\mathrm{N}=314\end{array}$ & $\begin{array}{c}\text { Nurses } \\
\mathrm{N}=83\end{array}$ & $\begin{array}{c}\text { Health } \\
\text { visitors } \\
\mathrm{N}=105\end{array}$ & $\begin{array}{c}\text { Midwives } \\
\mathrm{N}=126\end{array}$ & $\mathrm{p}$ \\
\hline CAM should be researched. & $192(61.7)$ & $44(54.3)$ & $74(71.2)$ & $74(58.7)$ & 0.043 \\
\hline $\begin{array}{l}\text { I think integration of CAM } \\
\text { methods into health care would } \\
\text { be effective. }\end{array}$ & $183(58.7)$ & $44(53.7)$ & $73(69.5)$ & $66(52.8)$ & 0.021 \\
\hline $\begin{array}{l}\text { I think only evidence based } \\
\text { CAM methods should be } \\
\text { taught. }\end{array}$ & $182(58.5)$ & $49(59.8)$ & $71(68.3)$ & $62(49.6)$ & 0.016 \\
\hline $\begin{array}{l}\text { In my opinion CAM should be } \\
\text { taught in higher education in } \\
\text { the field of medical and health } \\
\text { sciences. }\end{array}$ & 179 (57.2) & $42(51.2)$ & $69(65.7)$ & $68(54.0)$ & 0.089 \\
\hline \multicolumn{2}{|c|}{$*$ Percentages of 'agreed a little', 'agreed moderately', and 'agreed strongly' responses were combined } \\
\hline
\end{tabular}

\subsection{Evaluation of Complementary Medicine course}

One hundred and five (80.2\%) out of 131 students participating in the Complementary Medicine course concerned it to be useful $(27,81.8 \%$ nurses, $41,82.0 \%$ health visitors and $37,77.1 \%$ midwives). Most students suggested the education form as elective course $(65,33.5 \%)$, followed by optional $(44,22.7 \%)$, and compulsory $(18,9.3 \%)$ forms. Some students could not answer this question $(26,13.4 \%)$ and a minority of them $(2,1.0 \%)$ thought that the education of alternative medicine is not necessary in the higher education.

\section{Discussion}

Only a few previous studies have examined and compared different groups of health care students' attitudes towards CAM and their related knowledge [13,16,31,38] and this is the first study carried out in Hungary among these groups. Therefore, the primary focus of the present study was to assess and compare the views towards CAM among nursing, health visitor and midwifery students. We also determined the knowledge of, the personal use of and the perceived effectiveness of CAM therapies and students' opinions about the integration of CAM into undergraduate curricula and health care systems. 
In all groups, the attitudes of the respondents towards CAM were generally positive. There were no significant differences in nursing, health visitor and midwifery students' attitudes, although their opinions were different regarding whether CAM treatments can provide an answer in cases where conventional medicine has no solution. This result harmonizes with the findings of previous studies on nursing, midwifery, medical and pharmacy students [13-17,34,36]. The positive attitudes reflected in the results that over $70 \%$ of respondents agreed that CAM brings about an improvement in patients' well-being, and it is useful supplement to regular medicine and CAM does have important results and it can provide an answer in cases where conventional medicine has no solution. Since over $90 \%$ of respondents were female in our study, we had expected the same results because previous studies showed that female students had a more positive attitude towards CAM and they were more likely to use CAM than male students [34,39]. Despite having a positive attitude, about one-third of students attributed results of CAM in most cases to the 'placebo-effect' and about one-quarter of them are afraid that CAM can raise unfounded hopes. The reason of these results might be due to the fact that in spite of legal regulations many continue to engage in a practice without qualifications or without publicly recognized qualifications, which has led to ineffective treatment in many cases.

In the present study, the most known CAM modalities were massage, relaxation, acupuncture, herbal medicine, meditation and homeopathy. There was no significant difference among nursing, health visitor and midwifery students' knowledge. Other studies found poorer knowledge of CAM among practicing nurses [20]. The most commonly used (over 50\%) CAM modalities were herbal medicine, massage and relaxation and they were found as the most effective techniques. Previous studies also found massage and herbal medicine as the most commonly used techniques among students [14,34,37]. While most of the results showed 38$55 \%$ rates of personal use $[15,40]$ among medical and pharmacy students some studies reported higher self-use (above $70 \%$ ) by medical, pharmacy and nursing students [39,40]. Similarly to other studies $[15,34]$ it was found that the most used CAM modalities were perceived as the most effective. The highest knowledge and use of massage might be due to its importance in the curriculum and its popularity among Hungarians. The higher knowledge of relaxation and meditation might be due to some psychological courses where students had opportunity to learn and practice these techniques. Acupuncture and herbal medicine also compose the main parts of the Complementary Medicine course and they are among the popular CAM techniques in Hungary. This is the reason why students had high knowledge about them, although we do not have a direct population based survey about the use of acupuncture and herbal medicine in Hungary. Since herbal medicine is easily accessible (e.g. in drug stores) and easy to use it was not surprising that it was found as the most used CAM practices.

In the recent study, the Internet was found to be the most commonly used information source about CAM followed by TV or radio, other people (including family, relatives and friends), formal education and scientific journals or books. The only significant difference in getting information on CAM between nursing, health visitor and midwifery students was in using TV or radio. Previous studies also reported that the Internet, mass media and family were the most important information sources about CAM [34,37].

About $60 \%$ of the respondents indicated that CAM should be further researched and thought that the integration of CAM methods into the health care system would be effective. Students also believed that only evidence based CAM methods should be taught and the education of CAM should be in higher education in medical and health science fields. These results are supported by previous researches [14,37]. Although the formal education of CAM methods (e.g. Traditional Chinese Medicine, acupuncture, massage) is available at different educational levels and in different educational forms in Hungary the number of authentic professionals are 
relatively low. However in the last few years the higher education institutions took steps forward (e.g. University of Pécs founded a Confucius Institute of the Traditional Chinese Medicine in 2014 and University of Debrecen founded an Ayurveda Institute and department in 2015). Now the officially accepted educational and training requirements of the health care students do not contain the CAM as a compulsory element. Compared to the opinions of nursing and midwifery students significantly more health visitor students believed that the research of CAM is necessary and that only evidence based CAM methods should be taught and that the integration of CAM methods into health care would be effective. These results were not surprising because the highest number of students taking the Complementary Medicine course were health visitor students. During this two semester course (theory and practice) students obtain knowledge about the most popular and the most widely used CAM treatment methods in Hungary (e.g.: basic of Traditional Chinese Medicine, herbal medicine, acupuncture, massage, chiropractic, balneotherapy).

Although the attitudes of the students who participated in the Complementary Medicine course were more positive than the attitude of those students' who did not, the differences were not significant at any investigated items. The reason may be that attitude change depends on many factors, e.g. the influencing person's prestige and credibility, the recipient's basic attitude, beliefs, interest and intelligence, and depth of processing [41]. A further explanation for this result may be that in our study the majority of the students were females and the females basically had a more positive attitude for CAM, therefore the change was not significant. In a previous study involving only male medical students there was a positive but non significant trend on some items and on others a significant improvement concerning their attitudes and knowledge toward CAM [42]. The course was found to be useful among the participants and they reported a higher knowledge about Traditional Chinese Medicine, acupuncture and chiropractic than students who did not participate in this course. The reason for this may be that these practices are regarded as highlighted fields of the course. As we had expected significant differences were found in gaining information about CAM between students who participated and those who did not participate in the course. Participants preferred formal education while the others used scientific journals or books as information sources. Most students participating in the Complementary Medicine course suggested it be an elective instead of being an optional course, as currently is the case. Compared to students who did not participate in the course there were significantly more students among participants of Complementary Medicine course who agreed that the integration of CAM methods into health care would be effective and only evidence based CAM methods should be taught. One explanation for this result may be that the basic approach of Complementary Medicine course is that alternative medicine does not replace conventional medicine, but complements it. Moreover, it seems that the course increases the openness and awareness of the student.

In a study carried out at the University of Washington after the initiation of the CAM integration into the curriculum $70 \%$ of the students at all levels (undergraduate, master's, and doctoral) reported that their CAM knowledge increased, $50 \%$ of students said that level of CAM interest increased. Self-reported students' CAM competencies were significantly greater in 2006-2007 than in 2003-2004 [24]. It harmonizes with our results meaning that the integration of the CAM into the curricula has a positive impact on the knowledge of CAM and/or interest. It should be noted that there are two main methods to integrate CAM into the curriculum. One approach is the indirect strategy of infusing the curriculum with CAM materials which increase the competencies for both the students and the faculty. Another strategy is to develop specific CAM modules or required coursework for the student [24]. 
Our study had several limitations such as male: female ratio. As only a few male students were sampled, it was not possible to investigate gender differences. It is important to note, that in these specialties the majority of students are females. Secondly, using self-reported questionnaire answers could be influenced by social desirability, therefore, our results may not reflect the actual knowledge and/or experience of the respondents. Moreover, large numbers of CAM modalities were given in the questionnaire, so in future studies the number of CAM practice needs to be decreased. Furthermore, students had only one chance to complete the questionnaire and this may have contributed to the $60 \%$ response rate. Finally, only some information was gained about Complementary Medicine course. Therefore, in the future study students will be asked e.g. about what should have been taught.

\section{Conclusions}

Health care students' attitudes towards CAM were positive with no significant differences among nursing, health visitor and midwifery students. This study revealed relatively high percentages of knowledge about some CAM modalities. Similar to other studies reporting an average of $50 \%$ self-use of CAM modalities by health care students, our study showed more than $50 \%$ percentage of personal use in herbal medicine, massage and relaxation. As others have shown, the Internet was found in our study to be the most commonly used information source about CAM. Students believed that the integration of CAM methods and the teaching of this discipline in higher education are necessary, but mainly only evidence based CAM methods should be taught. No significant differences were observed in the attitudes towards CAM between students who participated and those who did not participate in the Complementary Medicine course. However, the knowledge of the students participating in the course increased about some CAM practices and participants preferred formal education as information sources. They recommended that the course be an elective of the curriculum instead of the present optional offer. Increasing the number of health care students in the Complementary Medicine courses would result in more future health care professionals obtaining reliable knowledge about CAM practices in order to make their work more effective.

\section{Acknowledgements}

We are thankful to the following colleagues of Health Faculty for their assistances in this study: Mónika Fucskó, Éva Huszti PhD, Lajos Hüse PhD, Imre Lipóczki MD, Gabriella Ludescher $\mathrm{PhD}$, Krisztina Gebriné Éles, Katalin Heinrichné Kőszegi, Andrea Toldiné Bélteki and also to Eileen Savage PhD of University College, Cork, Ireland.

\section{Footnotes}

${ }^{1}$ Prananadi is a compound Sanskrit word made up of the words "prana" (wind, life-giving energy) and "nadi" (channel). This Tibetan method uses hands-on, no-touch techniques to maintain or improve both physical and emotional health.

${ }^{2}$ Reiki method uses simple hands-on, no-touch, and visualization techniques, with the goal of improving the flow of life energy in a person

\section{Conflict of interest statement}

None. 


\section{References}

[1] Akinci AC, Zengin N, Yildiz H, Sener E, Gunaydin B. The complementary and alternative medicine use among asthma and chronic obstructive pulmonary disease patients in the southern region of Turkey. Int J Nurs Pract 2011;17571-82, doi:10.1111/j.1440-172X.2011.01976.x.

[2] Barnes PM, Bloom B, Nahin RL. Complementary and alternative medicine use among adults and children: United States, 2007. Natl Health Stat Report 2008;12:1-23.

[3] Büssing A, Ostermann T, Heusser P, Matthiessen PF. Usage of alternative medical systems, acupuncture, homeopathy and anthroposophic medicine, by older German adults. Zhong Xi Yi Jie He Xue Bao 2011;9:847-56.

[4] Fisher P, Ward A. Complementary medicine in Europe. Br Med J 1994;309:107-10.

[5] Kessler RC, Davis RB, Foster DF, Van Rompay MI, Walters EE, Wilkey SA, et al. Longterm trends in the use of complementary and alternative medical therapies in the United States. Ann Intern Med 2001;135:262-268.

[6] Akyol AD, Oz B. The use of complementary and alternative medicine by patients with cancer: in Turkey. Complement Ther Clin Pract 2011;17:230-4, doi:10.1016/j.ctcp. 2010.12.003.

[7] Molassiotis A, Fernandez-Ortega P, Pud D, Ozden G, Platin N, Hummerston S, et al. Complementary and alternative medicine use in colorectal cancer patients in seven European countries. Complement Ther Med 2005;13:251-7.

[8] Hu C, Zhang H, Wu W, Yu W, Li Y, Bai J, et al. Acupuncture for Pain Management in Cancer: A Systematic Review and Meta-Analysis. Evid Based Complement Alternat Med 2016;2016:1720239. doi: 10.1155/2016/1720239.

[9] Salehi A, Hashemi N, Imanieh MH, Saber M. Chiropractic: Is it Efficient in Treatment of Diseases? Review of Systematic Reviews. Int J Community Based Nurs Midwifery 2015; 3(4):244-54.

[10] Chang HY, Chang HL. A review of nurses' knowledge, attitudes, and ability to communicate the risks and benefits of complementary and alternative medicine. J Clin Nurs. 2015;24:1466-78. doi: 10.1111/jocn.12790.

[11] Lorenc A, Blair M, Robinson N. Personal and professional influences on practitioners' attitudes to traditional and complementary approaches to health in the UK. Journal of Traditional Chinese Medical Sciences 2014;1:148-155. http://dx.doi.org/10.1016/j.jtcms.2014.09.002

[12] Orkaby B, Greenberger C: Israeli nurses' attitudes to the holistic approach to health and their use of complementary and alternative therapies. J Holist Nurs. 2015;33(1):19-26. doi: $10.1177 / 0898010114542876$. 
[13] Yıldırım Y, Parlar S, Eyigör S, Sertöz O, Eyigör C, Fadıloğlu Ç, Uyar M. An analysis of nursing and medical students' attitudes towards and knowledge of complementary and alternative medicine (CAM). JCN 2010;19:1157-1166.

[14] Akan H, Izbirak G, Kaspar EC, Kaya ÇA, Aydin S, Demircan N, et al. Knowledge and attitudes towards complementary and alternative medicine among medical students in Turkey. BMC Complement Altern Med 2012;12:115.

[15] Awad AI, Al-Ajmi S, Waheedi MA. Knowledge, Perceptions and Attitudes toward Complementary and Alternative therapies among Kuwaiti Medical and Pharmacy Students. Med Princ Pract 2012;21:350-354, doi: 10.1159/000336216.

[16] Çamurdan Ç, Gül A. Complementary and alternative medicine use among undergraduate nursing \& midwifery students in Turkey. Nurse Educ Pract 2013;13:350-4, doi: 10.1016/j.nepr.2012.09.015.

[17] Greenfield SM, Brown R, Dawlatly SL, Reynolds JA, Roberts S, Dawlatly RJ. Gender differences among medical students in attitudes to learning about complementary and alternative medicine. Complement Ther Med 2006;14:207-12.

[18] Trail-Mahan T, Mao CL, Bawel-Brinkley K. Complementary and Alternative Medicine: Nurses’ Attitudes and Knowledge. Pain Manag Nurs 2013;14:277-286.

[19] Chu FY, Wallis M. Taiwanese nurses' attitudes towards and use of complementary and alternative medicine in nursing practice: a cross-sectional survey. Int J Nurs Stud 2007; 44:1371-8.

[20] Shorofi SA, Arbon P. Nurses' knowledge, attitudes, and professional use of complementary and alternative medicine (CAM): a survey at five metropolitan hospitals in Adelaide. Complement Ther Clin Pract 2010;16:229-34, doi:10.1016/j.ctcp.2010.05.008.

[21] Yom Y, Lee K. A comparison of the knowledge of, experience with, and attitudes toward complementary and alternative medicine between nurses and patients in Korea. J Clin Nurs 2008; 17:2565-2572.

[22] Kligler B, Gordon A, Stuart M, Sierpina V. Suggested curriculum guidelines on complementary and alternative medicine: recommendations of the Society of Teachers of Family Medicine Group on Alternative Medicine. Fam Med 2000;32:30-33.

[23] Kligler B, Maizes V, Schachter S, Park C.M, Gaudet T, Benn R, et al. Core competencies in integrative medicine for medical school curricula: A proposal. Acad Med 2004;79:521-531.

[24] Booth-Laforce C, Scott CS, Heitkemper MM, Cornman BJ, Lan MC, Bond EF, Swanson KM. Complementary and Alternative Medicine (CAM) attitudes and competencies of nursing students and faculty: results of integrating CAM into the nursing curriculum. J Prof Nurs 2010;26:293-300, doi:10.1016/j.profnurs.2010.03.003.

[25] National Center for Complementary and Alternative Medicine. Program announcement: request for proposals for CAM education grants. Bethesda, Md: National Institutes of Health, 1999. 
[26] Hegyi G. A komplementer medicina színes palettája és jelenlegi helyzete Magyarországon. Komplementer Medicina 2010;3:39-42 [article in Hungarian].

[27] Antal Z, Szántó Zs. A természetgyógyászat és az orvostudomány konfliktusa. Leltár. MTA Társadalmi Konfliktusok Kutató Központjának kiadványa. Budapest, 1992 [article in Hungarian].

[28] Buda L. Az alternatív medicina tudományos orvosláshoz való viszonyának, társadalmilélektani, egészség-szociológiai hátterének elemzése és az egészségügyi ellátásban betöltött szerepének komplex empirikus vizsgálata. PhD értekezés. Pécsi Tudományegyetem Általános Orvostudományi Kar 2013 [article in Hungarian].

[29] Országos Lakossági Egészségfelmérés OLEF2000. Kutatási jelentés. Országos Epidemiológiai Központ 2002, Budapest [article in Hungarian].

[30] Országos Lakossági Egészségfelmérés OLEF2003. Kutatási jelentés. Egészségügyi ellátás igénybevétele. Országos Epidemiológiai Központ 2005, Budapest [article in Hungarian].

[31] Baugniet J, Boon H, Ostbye T. Complementary/alternative medicine: comparing the view of medical students with students in other health care professions, Fam Med 2000; 32:178-84.

[32] Eisenberg DM, Kessler RC, Foster C, Norlock FE, Calkins DR, Delbanco TL. Unconventional medicine in the United States. Prevalence, costs, and patterns of use. N Engl J Med 1993;328:246-52.

[33] NCCAM (National Center for Complementary and Alternative Medicine): CAM basics. NCCAM, 2012, available at https://nccih.nih.gov/sites/nccam.nih.gov/files/D347_05-25-2012.pdf [access: 11 May 2016].

[34] Hussain S, Malik F, Ahmed A, Ahmed S, Riaz H, Abbasi N, Malik PM. Pakistani Pharmacy Students' Perception About Complementary and Alternative Medicine. Am J Pharm Educ 2012;76:21.

[35] Fadlon J, Granek-Catarivas M, Roziner I, Weingarten MA. Familiarity breeds discontent: Senior hospital doctors' attitudes towards complementary/alternative medicine. Complement Ther Med 2008;16:212-219, doi: 10.1016/j.ctim.2007.09.001.

[36] Harris IM, Kingston RL, Rodriguez R, Choudary V. Attitudes Towards Complementary and Alternative Medicine Among Pharmacy Faculty and Students. Am J Pharm Educ 2006; 70:Article 129.

[37] James PB, Bah AJ. Awareness, use, attitude and perceived need for Complementary and Alternative Medicine (CAM) education among undergraduate pharmacy students in Sierra Leone: a descriptive cross-sectional survey. BMC Complement Altern Med 2014;14:438, doi:10.1186/1472-6882-14-438.

[38] Alis O, Ganime S, Nuran B, Mumtaz MM, Nazan B, Isik B. An analysis of nursing and medical students' attitudes towards and knowledge of complementary and alternative medicine (CAM). J Altern Complement Med 2007;13:1007-1010; doi:10.1089/acm.2007.7168. 
[39] Wilkinson JM, Simpson MD. Complementary therapy use by nursing, pharmacy and biomedical science students. Nurs Health Sci 2001;3:19-27.

[40] Lie D, Boker J. Development and validation of the CAM Health Belief Questionnaire (CHBQ) and CAM use and attitudes amongst medical students. BMC Med Educ 2004;4:2.

[41] Aronson E. Mass communication, Propaganda, and Persuasion. in: Aronson E. The Social Animal. New York, NY: Worth Publishers; 2011, pp. 59-112.

[42] Al Mansour MA, Al-Bedah AM, AlRukban MO, Elsubai IS, Mohamed EY, El Olemy AT et al. Medical students' knowledge, attitude, and practice of complementary and alternative medicine: a pre-and post-exposure survey in Majmaah University, Saudi Arabia. Adv Med Educ Pract 2015;6:407-20. doi: 10.2147/AMEP.S82306. 